\title{
Comparison between endoloop and linear mechanical stapler for the appendicular stump closure
}

\section{Comparación entre ligadura con lazo hemostático y engrapadora mecánica lineal para e cierre de base apendicular}

\author{
Juan J. Granados-Romero ${ }^{1}$, Alan I. Valderrama-Treviñoº, Baltazar Barrera-Mera ${ }^{3 *}$, Karen Uriarte-Ruí $Z^{\star}$ \\ Rodrigo Banegas-Ruiz ${ }^{5}$ and Jesús C. Ceballos-Villalva ${ }^{4}$
}

${ }^{1}$ General Surgery Department, Hospital General de México; ${ }^{2}$ Experimental Immunotherapy and Tissue Engineering Laboratory; ${ }^{3}$ Department of Physiology; ${ }^{4}$ Student Research Support and Promotion Program (AFINES), Faculty of Medicine, UNAM; ${ }^{5}$ Department of Hand Surgery and Microsurgery, Instituto Nacional de Rehabilitation. Mexico City, Mexico

\begin{abstract}
Introduction: In the last decades, the approach by minimally invasive surgery of abdominal pathologies is growing dere to its evident benefits; the appendicular cases being the main surgical emergency, with different methods of closing the appendicular base. In this article, we compared the appendicular base closure with linear stapler and endoloop, to analyze the frequency of complications such as abscess, dehiscence and seroma. Method: A prospective, observational and descriptive study was conducted, with a total of 703 procedures, using 567 endoloop patients and 136 linear stapler, operated bȳ the same surgeon and surgical team, with a completed learning curve. Results: The complications referred in the present ștudy were patients with abscess $(n=5)$, dehiscence $(n=3)$ and seroma $(n=3)$. According to the phases of the appendiceal pathology: phase 1 or congestive appendix did not present complications; phase 2 or suppurative was reported one case of surgical wound dehiscence in the use of endoloop; in phase 3 or necrotic, one case of seroma was reported in a patient treated with endoloop; while in phase 4 or perforated there is a significant difference in the case of abscesses, reporting five in the use of endoloop and none in the case of a linear stapler. Conclusions: In our study there is no statistically significant difference between the use of linear stapler or endoloop in the early appendicular phases; being of significant utility in Phase 4 the use of linear stapler for the incidence of abscesses.
\end{abstract}

KEY WORDS: Endoloop. Mechanical lineal stapler. Appendicitis. Appendicular stump.

\section{Resumen}

Introducción: En las últimas décadas es creciente el abordaje por mínima invasión de patologías abdominales debido assus beneficios evidentes. El cuadro apendicular es la principal emergencia quirúrgica, con diferentes métodos del cierre de la base apendicular. En este artículo comparamos dicho cierre con engrapadora lineal o ligadura con lazo hemostático, \$para analizar la frecuencia de complicaciones como absceso, dehiscencia y seroma. Método: Se realizó un estudio prospectivo, observacional y descriptivo, con un total de 703 procedimientos, empleando en 567 pacientes ligadura con lazo hemostático y en 136 engrapadora lineal, operados por los mismos cirujano y equipo quirúrgico, con curva de aprendizaje concluida. Resultados: Las complicaciones referidas en el presente estudio son absceso $(n=5)$, dehiscencia $(n=3)$ y seroma $(n \subseteq \overline{\overline{0}} 3)$. De acuerdo con las fases de la patología apendicular: fase 10 apéndice congestivo, no presentaron complicaciones; fase 2

\author{
Correspondence: \\ *Baltazar Barrera-Mera \\ Departamento de Fisiología \\ Facultad de Medicina, UNAM \\ Av. Universidad 3000, \\ Del. Coyoacán, \\ C.P.06726, Mexico City, Mexico \\ E-mail: baltazar.barrera.mera @gmail.com
}

Date of reception: 14-03-2018

Date of acceptance: 15-05-2018

DOI: 10.24875/CIRUE.M18000065
Cir Cir. 2018;86:377ั7380

Contents available at PubMed www.cirugiaycirujanos.com 
o supurativo, se reportó un caso de dehiscencia de herida quirúrgica con el uso de ligadura con lazo hemostático; fase-3o necrótico, se reportó un caso de seroma en un paciente tratado con ligadura con lazo hemostático; y fase 4 o perforado, se encuentra diferencia significativa en el caso de abscesos, reportando cinco con el uso de ligadura con lazo hemostático y ninguno con engrapadora lineal. Conclusiones: En nuestro estudio no existe diferencia estadísticamente significativa êntre el uso de engrapadora lineal o ligadura con lazo hemostático en las fases apendiculares 1-3; en la fase 4 es de utifidad significativa el uso de engrapadora lineal ante la incidencia de abscesos.

PALABRAS CLAVE: Ligadura con lazo hemostático. Engrapadora mecánica lineal. Apendicitis. Base apendicular.

\section{Introduction}

Over the past few decades, the use of minimallyinvasive approaches to abdominal pathologies has been growing, especially in acute gynecological, vesicular and appendicular conditions, where offering a speedy recovery, decreasing postoperative pain and reducing the frequency of surgical site infections has been achieved in comparison with traditional open surgery ${ }^{1-4}$.

Acute appendicitis is the most common abdominal surgical emergency, and its current resolution approach is preferred using laparoscopic appendectomy, with different methods for appendicular stump closure, out of which the most commonly used are hemostatic loop ligation (endoloop), sutures, endoclips and linear staplers. An ideal closure should be resistant to traction, avoid infections or contamination, and elicit minimal local reaction by the tissue where it is placed $^{5}$. In this article, we compare two basic appendicular stump closure methods, linear stapler and endoloop, with the purpose to determine if there is difference between the rate of complications such as abscess, dehiscence and seroma. Ligation with endoloop is usually more economic than with linear stapler, which also requires a trocar incision that may require from 12 to $15 \mathrm{~mm}$, with the benefit of allowing a quick and efficacious closure of the appendicular stump, even in situations of appendicular perforation ${ }^{6-9}$. Regarding the duration of a laparoscopic surgery using linear stapler, it is 50 to 62 minutes, while the time reported with the use of endoloop is 47 to 75.4 minutes $^{10}$.

\section{Method}

A prospective, descriptive observational study was carried out, with 703 patients undergoing appendectomies by the laparoscopic route during the period of January 2014 to December 2017, at different private hospitals, operated by the same surgeon with a completed learning curve. This protocol was approved by the Hospital Ángeles Clinica Londres ethics and̄̄research committee, and authorization was requested to each patient by means of informed consent, where he/she could accept or refuse to be included in the study. In total, 703 procedures were included, out of which, in 567, ligation with endoloop was used and, in 136, linear stapler, with all procedures being performed by the same surgeon and surgical team, who had completed their learning curve. The electronic record-obtained database was collected in Micrósoft Excel 2016, and for statistical analysis, Fisher's exact test was used in the R program, with statistical significance being set at a $p$-value $<0.05$.

\section{Results}

Seven-hundred and three patients who underwent laparoscopic appendectomy were included; in 567, endoloop was used for appendicular stump closure $(80.65 \%)$, whereas in $136(19.34 \%)$, mechanical stapler was used.

The incidence of complications was studied and analyzed: abscess $(n=5)$, dehiscence $(n=3)$ and seroma $(n=3)$. The patients were grouped according to the appendicular condition phase (phases 1 to 4 ). Phase 1 corresponds to a congestive appendix; phase 2, suppurative; phase 3 , necrotic; and phase 4 , perforated. Once divided by phases, the number of patients who were operated with endoloop or stappler was recorded in order to compare and determine whether there is significant difference in the incidence of complications.

Within appendicular phase 1 , none of the abovementioned complications was found. In phase 2 , one dehiscence was found. In phase 3 , there was one case of seroma with the use of endoloop, but there is no statistically significant difference. In phase 4 , there is significant difference for the incidence of abscesses, since five abscesses occurred when using endotoop and none when linear stapler was used; for the remaining complications there is no significant difference with the use of either surgical technique (Table 1). 
Table 1. Comparison of the incidence of complications in appendicular stump closure

\begin{tabular}{llccc}
\hline Phase & Complication & Endoloop & Stapler & $\mathbf{p}$ \\
\hline 1 & Abscess & 0 & 0 & $>0.05$ \\
& Dehiscence & 0 & 0 & $>0.05$ \\
2 & Abscess & 0 & 0 & $>0.05$ \\
& Dehiscence & 1 & 0 & $>0.05$ \\
3 & Abscess & 0 & 0 & $>0.05$ \\
& Dehiscence & 0 & 0 & $>0.05$ \\
& Seroma & 1 & 0 & $>0.05$ \\
4 & Abscess & 5 & 0 & 0.00178 \\
& Dehiscence & 1 & 1 & 0.0518 \\
& Seroma & 2 & 0 & 0.08688 \\
\hline
\end{tabular}

\section{Discussion}

Among the 703 patients who underwent this procedure, there were only 11 complications $(1.56 \%)$, out of which $10(1.42 \%)$ occurred with the use of endoloop and one $(0.14 \%)$ corresponded to the linear stapler. Among these complications, there were 5 abscesses $(0.71 \%), 3$ cases of dehiscence $(0.42 \%)$ and 3 of seroma $(0.42 \%)$. According to Hilko Swank et al. ${ }^{4}$, the prevalence of intra-abdominal abscesses after laparoscopic appendectomy is $4.2 \%$, and that of wound infection is $0.5 \%$.

When the statistical analysis was performed, we found the following: in phases 1,2 and $3, p$-value was $<0.05$, and thus we cannot conclude that one closure method is better than the other; in phase 4 , the same is observed for complications such as seroma and abscess, but for dehiscence, a p-value $<0.05$ is observed, and it can be therefore concluded that, at this phase, the stapler causes less abscesses that endoloop.

Laparoscopic surgery has been shown to offer numerous benefits for the resolution of several pathologies, such as appendicitis, but controversy persists on the method for appendicular stump closure.

In 2017, Van Rossem et al. ${ }^{11}$ carried out a comparison between endoloop and stapler for the resolution of appendicitis by the laparoscopic route in 1,369 patients, with the purpose to analyze a possible relationship between the closure method and infectious complications, and concluded that the type of closure did not influence on complications, but appendicitis severity did. Sahm et al. ${ }^{12}$ assessed the effectiveness of the use of endoloop for appendicular closure in comparison with linear stapler, and found that endoloop ligation has no significant difference in terms of resulting complications. Miyano et al..$^{13}$ carried out a similar study, and concluded that there was no significant difference in laparoscopic appendectomy complications between the use stapler or endoloop. Safavi et al..$^{14}$ observed that the use of endoloo'p is preferable, since there is no significant difference with the stapler in terms of complications, but there $\overline{\bar{s}}$ in the cost-benefit ratio and, in addition, they stated that such complications may be due to the quality ofthe appendicular stump rather than to the closure technique. In contrast, Escolino et al. ${ }^{15}$ concluded that, although the use of stapler is more expensive than endoloop ligation, it should be used in complicated appendicitis with perforation or necrosis, since it was associated with a lower incidence of abscesses.

As for cost-benefit, in Switzerland, Beldi et ap16,17 demonstrated that the use of stapler costs $€ 248$ more than the use of endoloop. Kazemier et al. ${ }^{18}$ report that, in the European Union, the use of stapler increases the cost by $€ 300$ in comparison with endoloop figation. Miyano et al. ${ }^{13}$ refer that, in the USA, average operating cost using endoloop is USD \$ 890, while using the stapler it is USD $\$ 1,300$. Mehdorn et al. ${ }^{10}$ report that, in Germany, the use of the stapler is $€ 235$ more expensive than the use of endoloop.

In this article, we assess two methods, linear stapler and hemostatic loop ligation (endoloop). The linear stapler leaves metal staples on the stump and may cause future adhesions in the abdominal cavity or pseudopolyp formation in the cecum. As for ligation with endoloop, there is evidence that it reduces safety when used in a perforated appendix ${ }^{4}$. A crucial part of the procedure with this method is ligation manual fixation, with the possibility of insufficient closure and risk of appendicular stump abscess ${ }^{5}$. Endoloop is $\overline{6}$ to 12 times more economic than the use of linear stapler ${ }^{6}$.

\section{Conclusions}

In our study there is no statistically significantydifference between the use of linear stapler or endotoop in appendicular phases 1, 2 and 3. The same behavior is not observed in phase 4, particularly with regard to abscess, which shows a higher incidence with the use of endoloop. Owing to of this, we consider that the use of linear stapler might be adequate and timeloffor appendicular stump closure at phase 4 .

\section{Conflicts of interests}

The authors declare that they have no conflicts of interest. 


\section{References}

1. Sauerland S, Jaschinski T, Neugebeauer EA. Laparoscopic versus open surgery for suspected appendicitis. Cochrane Databases Syst Rev. 2010; (10):CD001546.

2. Starvos A, Dimitrios M, Shahab H, Hajibandeh S, Antoniou G, Gorter R et al. Optimal stump management in laparoscopic appendectomy: a network meta-analysis by the minimally invasive surgery synthesis of interventions and outcomes network. Surgery. 2017;162: 994-1005.

3. Taguchi $Y$, Komatsu. S, Sakamoto E, Norimizu D, Shingu Y, Hasegawa Laparoscopic versus open surgery for complicated appendicitis in adults: a randomized controlled trial. Surg Endosc. 2016;30:1705-12.

4. Swank HA Van Rossem CC, Van Geloven AAW, In't Hof KH, Kazemier G, Meijerink WJHJ, et al. Endostapler or endoloops for securing the appendiceal stump in laparoscopic appendectomy: a retrospective cohort study. Surg Endosc. 2014;28:576-83.

5. Delibegović S, lljazović E, Katica M, Koluh A. Tissue reaction to absorbable endoloop, nonabsorbable titanium staples, and polymer Hem-o-lok clip after laparoscopic appendectomy. JSLS. 2011;15:70-6

6. Naiditch J, Lautz T, Chin A, Browne M, Rowell E. Endoloop as the first line tool for appendiceal stump closure in children with appendicitis. Eur J Pediatr Surg. 2015;25:155-9.

7. Rakić M, Jukić M, Pogorelić Z, Mrklić I, Kliček R, Družijanić N, et al. Analysis of endoloops and endostaples for closing the appendicea stump during laparoscopic appendectomy. Surg Today. 2014;44 1716-22.

8. Bozkurt MA, Unsal MG, Kapan S, Gonenc M, Dogan M, Kalayci MU, et al. Is laparoscopic appendectomy going to be standard procedure for acute appendicitis; a 5-year single center experience with 1,788 patients. Eur J Trauma Emerg Surg. 2014;41:87-9.
9. Al-Temimi MH, Berglin MA, Kim EG, Tessier DJ, Johna SD. Endostapler versus Hem-O-Lok clip to secure the appendiceal stump and mesoappendix during laparoscopic appendectomy. Am J Surg. 2017;214:1143-8.

10. Mehdorn M, Schurmann O, Mehdorn MH, Gockel I. Intended cost reduction in laparoscopic appendectomy by introducing the endoloop a single center experience. BMC Surg. 2017;17:80.

11. Van Rossem CC, van Geloven AAW, Schreinemacher MHF, Bemelman WA. Endoloops or endostapler use in laparoscopic appendectomy for acute uncomplicated and complicated appendicitis: no difference in infectious complications. Surg Endosc. 2017;31:178-84.

12. Sahm M, Kube R, Schmidt S, Ritter C, Pross M, Lippert H. Current analysis of endoloops in appendiceal stump closure. Surg Endosc. 2011; 25:124-9.

13. Miyano G, Urao M, Lane G, Kato Y, Okazaki T, Yamataka A. Appendíceal stump closure in children with complicated appendicitis: a prospective analysis of endoloops versus endostaples. Asian J Endosc Surg. 2011;4:116-9.

14. Safavi A, Langer M, Skarsgard ED. Endoloop versus endostapler Closure of the appendiceal stump in pediatric laparoscopic appendectomy. Can J Surg. 2012;55:37-40.

15. Escolino M, Bacmeur F, Saxena A, Holger T, Holcomb G, Esposito C. Endoloop versus endostapler: what is the best option for appendiceal stump closure in children with complicated appendicitis? Results of a multicentric international survey. Surg Endosc. 2018;32:3570-5. .

16. Beldi G, Muggli K, Helbing C, Schlumpf R. Laparoscopic appendectomy using endoloops: a prospective, randomized clinical trial. Surg Endosc. 2004; $18: 749-50$

17. Beldi G, Vorburger SA, Bruegger LE, Kocher T, Inderbitzin D, Candiñas D. Analysis of stapling versus endoloops in appendiceal stump closure. $\mathrm{Br}$ J Surg. 2006;93:1390-3

18. Kazemier G, In't Hof KH, Saad S, Bonjer HJ, Sauerland S. Securing the appendiceal stump in laparoscopic appendectomy: evidence for routine stapling? Surg Endosc. 2006;20:1473-6. 